\title{
Projeto de arborização como patrimônio da cidade
}

\author{
Urban forestation project as the city's heritage
}

\section{Andréia Gonçalves \\ Karin Schwabe Meneguetti}

\section{Resumo}

A

arborização urbana é um elemento de grande importância para a qualidade do espaço urbano e colabora também para a formação da memória e do patrimônio cultural das cidades. O projeto paisagístico pode garantir à cidade características espaciais de significativo valor estético. Esta pesquisa analisou o conjunto arbóreo viário do plano inicial da cidade de Maringá, PR, implantado a partir de um projeto de arborização que teve forte apelo estético. A pesquisa foi dividida em quatro processos: simulação do projeto de arborização inicial da cidade, por meio do mapeamento da distribuição dos indivíduos arbóreos ao longo das vias de toda a área de estudo; análise da paisagem atual, levantada in loco e registrada por meio de fotografias, que identificou a situação em que se encontra o conjunto arbóreo das vias; análise comparativa entre o projeto de arborização implantado e a condição atual do conjunto arbóreo, com a identificação dos principais fatores que influenciam o desenvolvimento e a preservação da arborização; e, por fim, a proposição de um projeto de rearborização. Este projeto busca solucionar os problemas causados principalmente pelo envelhecimento dos espécimes, o que acarreta a necessidade de substituição, para preservar as características estéticas da paisagem, advindas da unidade do conjunto arbóreo implantado.

Palavras-chaves: Arborização urbana. Conjunto arbóreo. Patrimônio paisagístico. Paisagem urbana. Maringá - PR.

Andréia Gonçalves Universidade Estadual de Maringá Maringá - PR - Brasil

Karin Schwabe Meneguetti Universidade Estadual de Maringá Maringá - PR - Brasil

Recebido em 01/07/14 Aceito em 05/05/14

\begin{abstract}
Urban forestation is a crucially important element for the quality of the urban space, contributing also to the formation of the memory and cultural heritage of cities. Landscape design can ensure special characteristics of significant aesthetic value to the city. This study analysed the group of trees lining the streets of the city of Maringá-PR present in its initial master plan, implemented based on an urban forestation concept concept that has great aesthetic appeal. This study was divided into four stages: i) simulation of the city's initial urban forestation plan by mapping the distribution of individual types of trees planted along the streets in the study area; ii) analysis of the current landscape conducted in loco and photographically recorded, identifying the present situation of the group of trees along the streets; iii) comparative analysis of the urban forestation project originally implemented and the present condition of the trees, identifying the main factors influencing the development and preservation of the trees; and, finally, iv) proposing a re-forestation project. This project aims to solve the problems caused mainly by the aging of specimens, which has resulted in the need to replace old trees and preserve the aesthetic characteristics of the landscape established by the totality of the tree groups planted.
\end{abstract}

Keywords: Urban arborization. Tree group. Landscape heritage. Urban landscape. Maringá-PR 


\section{Introdução}

A arborização no ambiente urbano promove uma infinidade de benefícios. $O$ verde urbano possibilita a sustentabilidade da vida humana, é um indicativo da qualidade estética da cidade e reflete a biodiversidade dos ecossistemas urbanos. No entanto, a falta de planejamento para a implantação e manutenção da arborização urbana acaba por prejudicar suas qualidades.

A cidade de Maringá é amplamente conhecida por sua vasta arborização urbana e por seu traçado viário baseado nos conceitos de cidade-jardim. Ruas e avenidas largas e bem arborizadas são as principais características da paisagem urbana. Porém, essa mesma arborização que confere tantos elogios à cidade, nascida do projeto do engenheiro florestal Luiz Teixeira Mendes e mantida com os cuidados de Aníbal Bianchini da Rocha, está envelhecendo e foi tomada, ao longo dos anos, por retiradas, plantios e podas irregulares. $\mathrm{O}$ resultado é a perda da unidade no conjunto arbóreo formado pelas vias públicas.

Nesse contexto, esta pesquisa estudou a arborização viária do plano urbanístico inicial da cidade de Maringá, tendo abordado esse elemento como patrimônio histórico, estético e paisagístico da cidade, e apontou diretrizes que podem fomentar a preservação de seu conjunto arbóreo.

Em Maringá, o projeto de arborização implantado no plano inicial da cidade tinha como objetivo melhorar as condições climáticas da cidade. No entanto, devido às particularidades dos espécimes vegetais empregadas, garantiu às ruas e avenidas formatos, texturas e cores diferenciados, o que proporcionou à cidade características espaciais únicas, que a qualificam e identificam devido ao significativo valor estético (MENEGUETTI et al.,2010). As ruas e avenidas largas oriundas de um traçado urbanístico baseado nos conceitos de cidade-jardim foram completadas com a implantação de um rico projeto paisagístico.

No entanto, essa arborização tem sofrido ao longo dos anos, com diminuição de sua qualidade e número de exemplares. Esse fato ocorre devido ao próprio envelhecimento dessa vegetação, assim como pela falta de entendimento da arborização da cidade como um conjunto formado por um somatório de espécimes arbóreos, em que cada espécime retirado ou inserido sem planejamento adequado compromete a unidade do conjunto.

Desse modo, compreender que a arborização urbana é um patrimônio natural e cultural da cidade torna-se essencial para estabelecer parâmetros e diretrizes para sua manutenção e preservação. Para tanto, o projeto de arborização de Maringá deve ser entendido como obra de arte, considerando seus aspectos estéticos e históricos, além dos técnicos e fitossanitários.

A análise da arborização realizada buscou entender como ocorreram os processos de formação, desenvolvimento e evolução da arborização de acompanhamento viário.

A pesquisa discute a preservação e a restauração do patrimônio arbóreo de Maringá, de que maneira elas devem ser feitas, e nos casos em que seja necessária a retirada de um exemplar arbóreo qual deverá ser implantado no local.Outra questãoa que se responde é como lidar com a inserção de novos espécimes ao longo do conjunto arbóreo.

\section{Conjuntos urbanos e paisagísticos como patrimônio cultural}

A origem do termo "patrimônio" está ligada às estruturas familiares: patrimônio é "[...] bem de herança transmitido dos pais aos filhos [...]" (CHOAY, 2006, p. 11). É o legado que o homem recebe do passado, vive no presente e transmite às futuras gerações.

O Instituto do Patrimônio Histórico e Artístico Nacional (Iphan) classifica o conceito do patrimônio brasileiro, no qual afirma:

\section{[...] não se restringe apenas a imóveis oficiais isolados, igrejas ou palácios, mas na sua concepção contemporânea se estende a imóveis particulares, trechos urbanos $e$ até ambientes naturais de importância paisagística, passando por imagens, mobiliário, utensílios e outros bens móveis. (INSTITUTO..., 2013, grifo nosso).}

O patrimônio representa a identidade das cidades e de sua população, sua história, seus costumes e tradições. Assim, ele é demasiadamente importante na formação da memória, da identidade e da criatividade da população.

Nesta pesquisa, identificaram-se os conjuntos urbanos e paisagísticos como patrimônio cultural. No caso de Maringá, a arborização é o elemento característico de determinadas áreas, representativo da imagem e identidade de uma paisagem urbana, contrasta com seus elementos construídos e proporciona maior qualidade visual à paisagem, por meio de suas cores, texturas e transformações. 
As modificações sazonais pelas quais as árvores passam vão mudando a paisagem ao longo do ano, o que também desperta a atenção dos observadores. A qualidade estética da arborização gera o embelezamento das cidades, o que faz com que a população inclua a vegetação no imaginário da paisagem urbana.

Assim, torna-se fundamental considerar os conjuntos urbanos e paisagísticos como patrimônio cultural. O patrimônio a ser preservado deve ser selecionado com base "[...] num grau de significação e de coerência abrangentes [...]", para que permitam a reconstrução de vínculos perdidos ou ameaçados (BENEVOLO, 2004, p. 141).

Da mesma forma, o valor da arborização maringaense como patrimônio e elemento formador da identidade da cidade está diretamente ligado ao conjunto, e não apenas aos exemplares arbóreos isolados. Os elementos analisados isoladamente não são representativos da paisagem urbana, de sua beleza e efeitos de sombreamento. Os elementos que compõem a arborização maringaense "[...] são percebidos uns em relação aos outros, e não de forma isolada [...]" (SILVEIRA et al., 2006, p.5, grifo nosso).

De acordo com Silveira et al. (2006, p. 5):

\section{[...] o projeto paisagístico constitui-se como um unicum, ou seja, como uma concepção projetual que não é reproduzível à vontade, seja pelas diferenças topográficas, climáticas, ambientais e arquitetônicas que diferenciam Maringá das demais cidades. A figuratividade resultante dessa relação da arborização com o meio garante a sua particularidade.}

De acordo com Brandi (2004), a unidade do conjunto "concerne ao inteiro, e não a unidade que se alcança no total", ou seja, o conjunto deve ser entendido como único, e não como a somatória das partes.

Fazendo referência à obra de Brandi (2004), Silveira et al. (2006, p.8) enfatizam que "as intervenções que a obra recebeu ao longo dos anos fazem parte de sua história"; no entanto, elas devem ser analisadas do ponto de vista estético, e, caso essas intervenções comprometam "a fruição da obra", devem ser removidas.

De acordo com Brandi (2004, p.30), a restauração constitui o "reconhecimento da obra de arte", em sua instância estética e histórica, com o objetivo de sua preservação e "transmissão para o futuro". Sendo assim, a conservação e a remoção de intervenções devem ser feitas considerando a instância histórica e a esteticidade.
Responder a essas questões é o desafio desta pesquisa, diante da importância da função da arborização como formadora da identidade urbana. Tem-se em vista que a arborização implantada pelo projeto de Luiz Teixeira Mendes faz parte da formação e do desenvolvimento da cidade, presente em sua paisagem desde seus primeiros anos de formação. Assim, além de fazer parte da paisagem de Maringá como elemento embelezador do espaço urbano, também faz parte da história da cidade e de seus habitantes, sendo testemunha do crescimento e da evolução dela.

\section{Maringá: traçado urbano e arborização}

A cidade de Maringá (Figura 1) nasceu de um empreendimento comercial que teve características únicas, a colonização do norte do Paraná pela Companhia de Terras Norte do Paraná (CTNP), mais tarde chamada de Companhia Melhoramento Norte do Paraná (CMNP).

O projeto da cidade de Maringáfoi encomendado ao engenheiro Jorge de Macedo Vieira pela CMNP, responsável pela colonização da região a partir de 1944. No desenho da cidade, o engenheiro utilizou-se de soluções do tipo garden city, influenciado por seu convívio profissional com Barry Parker durante o desenvolvimento dos bairros-jardins da Cia. City ${ }^{1}$ em São Paulo. Assim sendo, a paisagem construída através do projeto de Vieira respeitou todas as particularidades e potencialidades que o cenário natural lhe oferecia (REGO, 2001).

[...] o plano de Maringá se distingue pela presença de inúmeros elementos que vão conferir uma qualidade urbanística diferenciada à cidade, como o desenho das principais avenidas e ruas com calhas amplas e canteiros centrais, as rotatóriasjardins nos principais cruzamentos viários, além de farta arborização em quase toda a cidade, configurando-a como uma autêntica cidade-jardim, ainda que sem muitos dos requisitos sociais e fundiários daquela concebida por Howard e realizada pioneiramente por Unwin e Parker nos arredores de Londres (ANDRADE; CORDOVIL, 2008, p. 7).

${ }^{1}$ The City of S. Paulo Improvements \&Freebold Land Co. Ltda Empresa de urbanização fundada por ingleses, estabeleceu-se no Brasil em 1917, conhecida pela atuação no planejamento de bairros com o conceito de "cidade-jardim". 
Figura 1- Localização do Município de Maringá

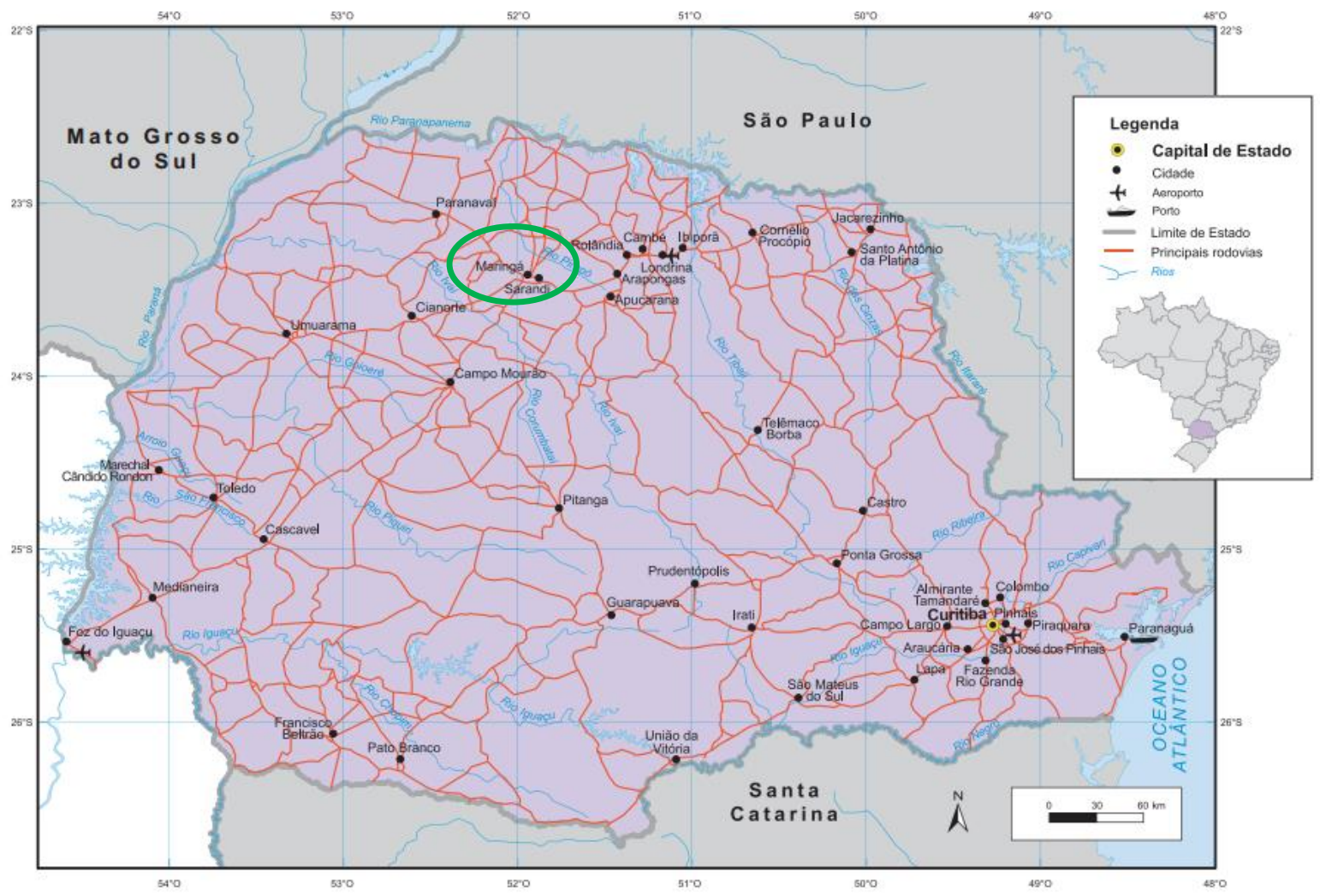

Fonte: adaptado de Guia Geográfico (2015).

Os conceitos de cidade-jardim de Ebenezer Howard podem ser vistos no projeto de Jorge de Macedo Viera, na organicidade do traçado e na adequação do espaço urbano à paisagem local, assim como na presença de parques e amplos espaços públicos (Figura 2). Pode-se observar o sistema viário de pouca declividade e de vias amplas, que foram conferidas posteriormente por vasta arborização. A presença de ruas largas e de um jardim urbano enfatizava o caráter de cidade idealizada. $\mathrm{O}$ urbanista procurou preservar espaços abertos, incluindo remanescentes de floresta nativa e outras áreas verdes. Três áreas de conservação fizeram parte do projeto original a pedido da CMNP, que estava preocupada com a qualidade ambiental danova cidade,uma vez que a área para a implantação da cidade haviaperdido sua cobertura vegetal (MACEDO, 2011).

A arborização urbana da cidade de Maringá foi uma preocupação posterior ao projeto da cidade, mas, de acordo com Meneguetti (2009), encontrou condições ideais para a implantação dos espécimes na largura das vias, calçadas e canteiros centrais.

A empresa loteadora, ciente das condições adversas do clima local, adotou a farta arborização das vias como diferencial de conforto urbano e imagem da cidade (MENEGUETTI; REGO;
BELOTO, 2009), já que o sucesso do empreendimento comercial da Companhia dependia de uma imagem sedutora, e a vegetação nativa e exótica satisfez aquela condição (REGO, 2001).

Assim, a arborização urbana e o ajardinamento poderiam refletir de forma efetiva a ocupação da área desbravada recentemente e certificariam "[...] o controle sobre o ambiente hostil e o zelo pela obra urbana em andamento [...]" (MENEGUETTI et al., 2010, p.5).Ainda nos dias atuais, na área pertencente ao projeto original, é possível ver que cada rua ou avenida pode ser identificada por seu espécime arbóreo (Figura 3). Com o passar do tempo, a vegetação criou túneis verdes sobre a via pública e melhorou as condições do clima urbano (MENEGUETTI et al., 2010).

A efetivação do plano de arborização da cidade a Companhia confiou a Luiz Teixeira Mendes, um especialista conceituado em São Paulo, engenheiro florestal pela Escola Superior de Agricultura Luiz de Queiroz, em Piracicaba, que foi professor de botânica e silvicultura nessa mesma instituição (RECCO, 2005).

Luiz Teixeira Mendes criou um plano completo de arborização para Maringá, mas, infelizmente, não 
há registros gráficos desse plano. Acredita-se que tenha sido realizado sem projeto gráfico, apenas com a especificação de espécimes em tabelas para cada logradouro. Teixeira Mendes teve como assistente Aníbal Bianchini da Rocha, cafeicultor na região de Maringá, engenheiro agrônomo pela ESALQ, que já prestava serviços ao escritório da Companhia em Maringá. Assim, os dois viajaram pela região e por outros estados "[...] em busca de mudas e sementes destinadas à multiplicação [...]" (RECCO, 2005, p.50).
A arborização de acompanhamento viário implantada na cidade priorizava espécimes de grande porte e rápido crescimento, visando amenizar o clima quente e dar continuidade à vegetação existente no entorno da cidade. A diversidade de espécimes garantiu florações subsequentes em diferentes partes da cidade durante a maior parte do ano, fato que reforça o princípio estético do projeto e promove a qualidade de vida na área urbana. Em um passeio pela cidade é possível identificar algumas avenidas por sua arborização característica (REGO, 2001).

Figura 2 - Projeto de Maringá, traçado de Jorge de Macedo Vieira

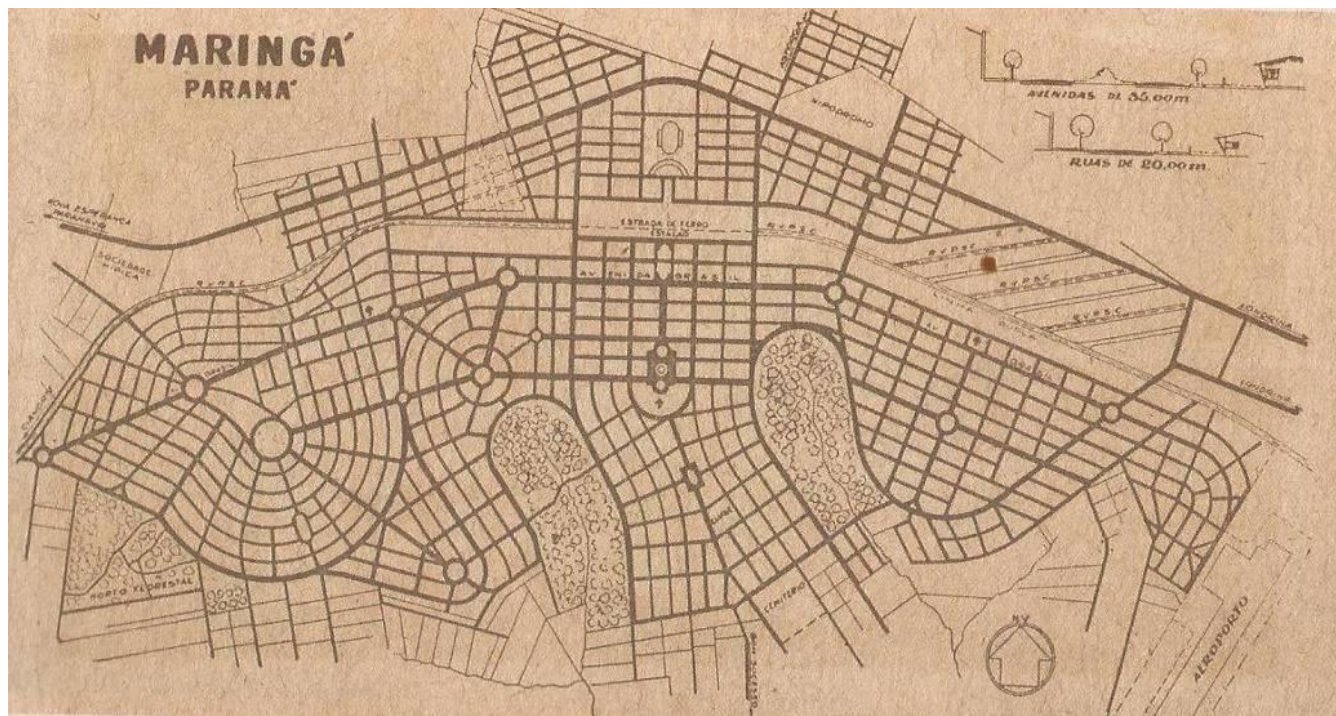

Fonte: Recco (2005).

Figura 3-Figueiras brancas na Avenida Luiz Teixeira Mendes- Zona 5

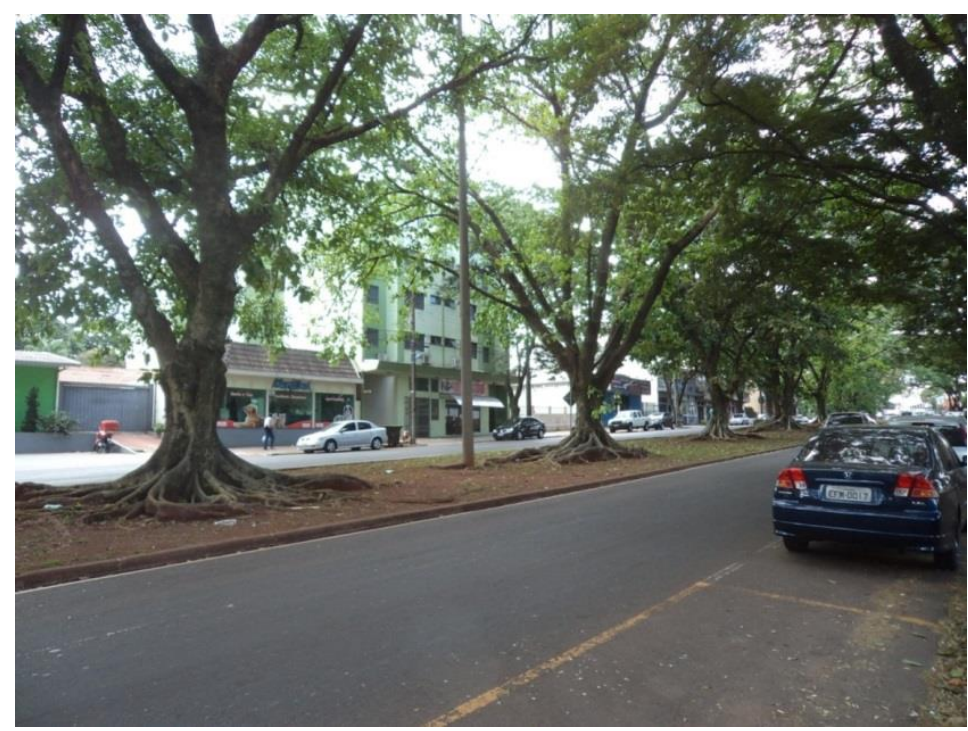

Fonte: foto da autora (2013). 
Segundo Rego (2001), com a implantação do plano paisagístico, com a arborização das vias, a paisagem urbana ganhou "variedade e encanto", conforme recomendava Unwin (1984). As ruas foram hierarquicamente classificadas e diferenciadas pela largura, pela presença do canteiro central com uma terceira fileira de árvores nas vias principais. O emprego de diferentes espécimes, uma para cada via, conferiu individualidade a elas, opondo-se a ideia de uniformização da cidade (REGO, 2001; MENEGUETTI, 2003; MENEGUETTI et al., 2010).

Meneguetti et al.(2010, p. 7) descrevem a paisagem urbana maringaense oriunda do projeto urbano inicial de Jorge Macedo Vieira e do projeto paisagístico da seguinte forma:
No desenho urbano de Maringá, a identidade urbana e sua unicidade foram forjadas pela consonância com as circunstâncias topográficas e reforçadas pela arborização urbana, distinta dos demais projetos de arborização urbana encontrados nas cidades brasileiras. Além de caracterizar-se como obra concebida por um fazer humano específico, o projeto paisagístico constitui-se como um unicum, ou seja, como uma concepção projetual que não é reproduzível à vontade, seja pelas diferenças topográficas, climáticas, ambientais ou arquitetônicas que diferenciam Maringá das demais cidades. A figuratividade resultante dessa relação da arborização com o meio garante a sua particularidade.

Meneguetti, Rego e Pellegrino (2005) caracterizam Maringá como uma cidade privilegiada com relação a sua arborização urbana. Isso porque a Companhia colonizadora preocupou-se com o plantio sistêmico de espécimes nativos e exóticos, assim como com o controle da qualidade e com manutenção das mudas.

As qualidades artísticas da arborização urbana de Maringá não estão somente nas qualidades individuais de cada espécime, mas sim na integridade do conjunto (Figura 4). Sendo assim, para entendimento da arborização como patrimônio, deve-se compreender que a singularidade desse bem reside na integridade do conjunto da cobertura vegetal (MENEGUETTI et al., 2010). De acordo com Lynch (1999), é a continuidade, dada pela repetição de intervalos rítmicos, pela similaridade, analogia e harmonia, que facilita a percepção da paisagem e que atribui a ela uma identidade única.

Ainda de acordo com Meneguetti et al. (2010), a arborização de Maringá acabou conferindo à cidade características espaciais únicas, que a qualificam e a identificam. $O$ conjunto urbano formado pelo projeto de arborização e traçado da cidade configurou uma paisagem cultural de significativo valor estético, um ambiente com qualidades estéticas, históricas e culturais relevantes. Os autoresacima citadosressaltam que

[...] compreender que a arborização urbana e o traçado da cidade são partes indissociáveis de sua paisagem cultural torna-se essencial para estabelecer parâmetros e diretrizes para a sua preservação [...]. (MENEGUETTI et al., 2010, p. 1).

Figura 4 - Tipuanas na Rua Américo Brasiliense- Zona 7

Fonte: foto da autora (2013).

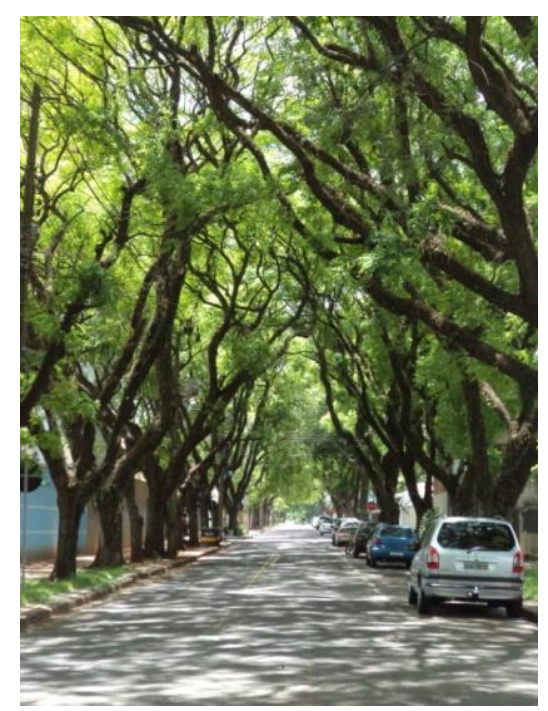

104 Gonçalves, A.; Meneguetti, K. S. 
Segundo Meneguetti (2001), a população identifica-se com o verde urbano tanto quanto com um objeto de arquitetura ou uma tradição cultural. Atualmente, a arborização urbana configura-se como um dos bens mais significativos da memória e da identidade dos maringaenses. Esse reconhecimento é fundamental para a preservação (MENEGUETTI et al., 2010).

\section{Método}

Esta pesquisadetém-se no plano inicial da cidade de Maringá, PR, em seu recorte espacial (Figura 5). A arborização desse trecho urbano foi implantada no decorrer da década de 1950, sendo a mais antiga no contexto da cidade e, portanto, mais vulnerável. Essa área possui aproximadamente 118 hectares e foi escolhida para o estudo por tratar-se do plano inicial da cidade, onde foram aplicados conceitos urbanísticos de cidade-jardim, o que proporciona condições adequadas à implantação da arborização, como a presença de canteiros centrais nas principais avenidas e passeios amplos.

A metodologia utilizada nesta pesquisa consistiu em quatro etapas.

Simulação do projeto de arborização inicial implantado pela Companhia Melhoramentos Norte do Paraná (CMNP) na formação da cidade: essa simulação consistiu no mapeamento da distribuição dos espécimes arbóreos implantados no plano de arborização original de autoria de Luiz Teixeira Mendes. Para tanto foi utilizado como base o inventário qualiquantitativo realizado por Sampaio (2006) e foi realizada uma verificação in loco dos espécimes remanescentes desse plano, percorrendo e analisando todas as vias pertencentes ao recorte urbano de estudo. Essa simulação foi importante, uma vez que esse tipo de informação era inexistente na cidade, ou seja, não há registro gráfico do plano de arborização inicial.

Figura 5 - Município de Maringá - Área de estudo

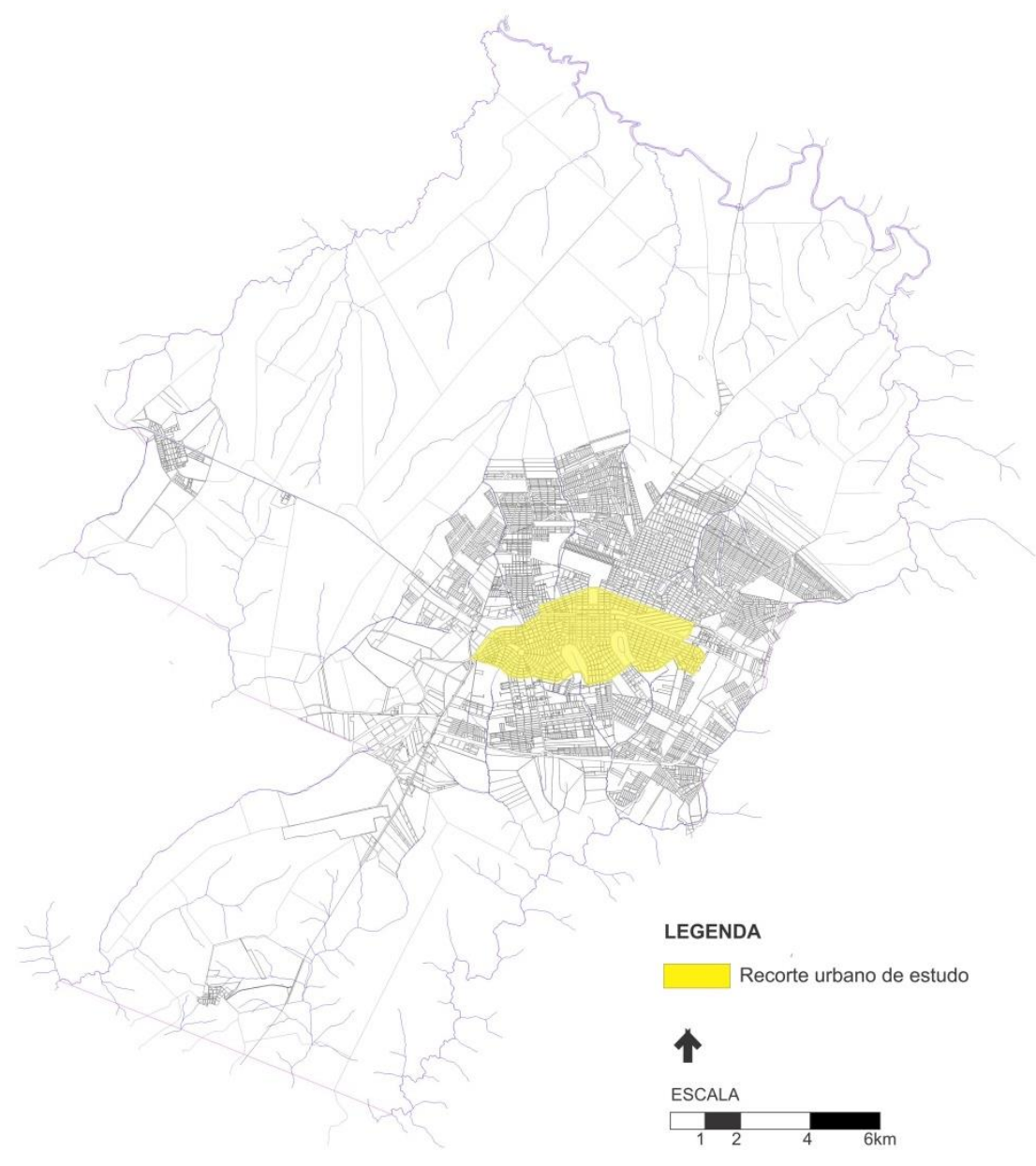

Fonte: Prefeitura do Município de Maringá(2015). 
Comparação do projeto inicial com a situação atual da arborização: foi realizado levantamento fotográfico em todas as vias da área de estudo com o objetivo de identificar a condição atual dos conjuntos implantados no projeto de arborização inicial da cidade. As imagens foram complementadas por anotações e croquis, quando necessário, visando apreender informações relevantes ao objetivo da pesquisa, como a largura das vias, canteiros e passeios, áreas permeáveis, recuo das edificações e aspectos referentes à arquitetura das árvores (formato, tamanho, cores, texturas).

Análise dos conflitos e das potencialidades: por meio da comparação entre a simulação do projeto de arborização inicial e as imagens que demonstram a situação atual da arborização, identificaram-se quais os principais fatores que influenciaram o desenvolvimento e as condições atuais da arborização.

Proposição de um projeto de rearborização para o plano inicial de Maringá: a quarta etapa consistiu na produção de um projeto de rearborização para o recorte urbano pertencente ao plano inicial da cidade, considerando as características funcionais, ambientais e estéticas da paisagem existente.

Dessa forma, a área de estudo foi dividida em dez unidades de paisagem (Figura 6), de acordo com suas características espaciais e paisagísticas, advindas do traçado urbano, sistema viário e uso e ocupação do solo. Como o plano urbanístico de
Jorge de Macedo Vieira para Maringá contou com um rígido zoneamento, reforçado pela morfologia de seu traçado, a subdivisão da área de estudo deuse basicamente pela divisão da área por bairros. Sendo assim, as unidades de paisagem foram assim divididas e nomeadas: unidade de paisagem Central, Novo Centro, Zona 2, Zona 3, Zona 4, Zona 5, Zona 6, Zona 7, Zona 8 e, finalmente,unidade de paisagem Zona 10.Decidiuse nomear as unidades de paisagem de acordo com os bairros que elas representam, portanto não existe a unidade de paisagem Zona 9, tendo em vista que o bairro Zona 9 (destacado na Figura 6) foi agrupado aosdemais bairros na divisão em unidades de paisagem.

\section{Resultados e discussão}

Neste item o objetivo é demonstrar e discutir os resultados alcançados com a aplicação da metodologia da pesquisa.

\section{Simulação do projeto de arborização inicial}

A simulação do projeto de arborização inicial consiste na representação por meio do mapeamento da arborização predominante nas vias das unidades de paisagem, com o intuito de simular como foi previsto o projeto de arborização do engenheiro florestal Luiz Teixeira Mendes e identificar quais espécimes foram implantados.

\section{Figura 6 - Subdivisão da área de pesquisa em unidades de paisagem}

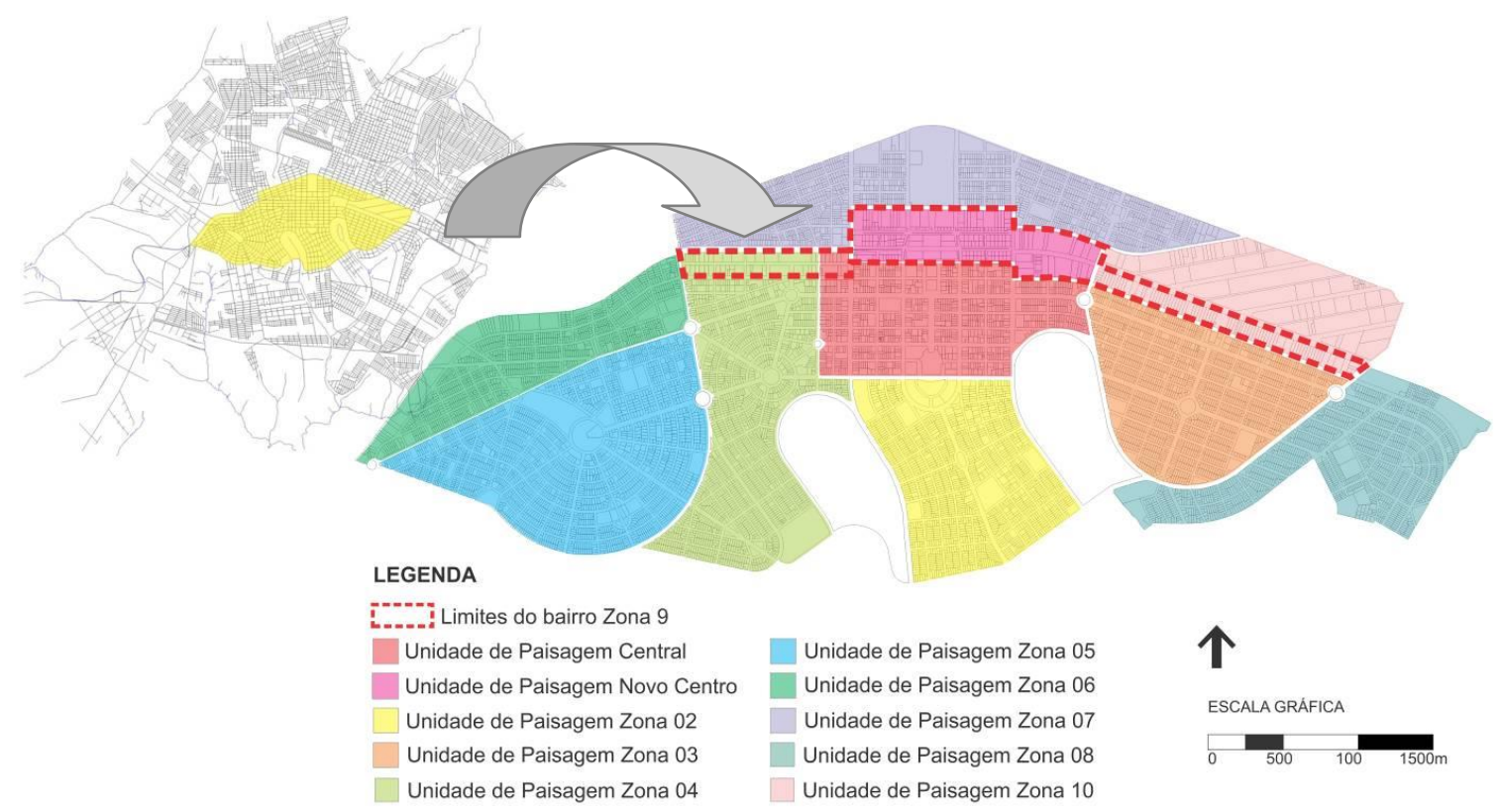

Fonte: adaptado de Prefeitura do Município de Maringá (2015). 
A partir da análise do inventário em tabelas realizado por Sampaio (2006) e diante do levantamento realizado em campo, pode-se identificar 19 espécimes arbóreos predominantes na área do Plano Inicial de Maringá, intencionalmente plantadas pela Companhia colonizadora. São elas: sibipiruna (Caesalpinia peltophoroides), tipuana (Tipuana tipu), ipê-roxo (Tabebuia avellanedae), ipê-amarelo (Tabebuia chrysotricha), flamboyant (Delonix regia), palmeira-imperial (Roystonea spp), alecrim (Holocalyx balansae), pau-ferro (Caesalpinia ferrea var. leiostachya), jacarandá-mimoso (Jacaranda mimosaefolia), bisnagueira (Spathodea campanulata), tamareira (Phoenix dactylifera), ligustro (Ligustrum lucidum), extremosa/resedá (Lagerstroemia indica), aroeira-salsa (Schinus molle), grevílea (Grevilea robusta), figueirabranca (Ficus guaranitica), quaresmeira (Tibouchina granulosa), Peroba (Aspidosperma polyneuron) e pata-de-vaca (Bauhinia forficata).

Pode-se observar que, apesar de a área analisada conter oito bairros, a variedade de espécimes implantados não foi muito grande. Além disso, ocorre predominância significativa do espécime sibipiruna, devido a suas características de crescimento rápido, grande sombreamento e facilidade na produção das mudas, como já foi destacado.

Esses espécimes foram representados em mapas individuais para cada unidade de paisagem, de acordo com sua distribuição pelo projeto de arborização de Teixeira Mendes. Foram excluídos espécimes plantados posteriormente, em desacordo com o plano inicial; ou seja, quando foram identificados poucos exemplares de espécimes diferenciados, diante da predominância de exemplares de um único espécime, estes foram excluídos do mapeamento. A Figura 7 ilustra, como exemplo, a simulação do plano de arborização inicial na unidade de paisagem Zona 4, os espécimes implantados, sua frequência e forma de distribuição ao longo das vias.

\section{Condição atual da arborização}

A condição atual da arborização foi observada por meio de levantamento in loco em todas as vias das dez unidades de paisagem, por meio de observação e registro fotográfico do conjunto arbóreo, destacando a presença de lacunas, ou seja, as falhas na arborização e trechos onde há inserção de espécimes diferentes dos implantados no projeto de Teixeira Mendes, assim como o destaque aos trechos onde a arborização encontra-se preservada.

Observou-se que a retirada de árvores (lacunas) e inserção de novos espécimes sem prévio planejamento é comum em todas as unidades de paisagem. Essas lacunas na arborização prejudicam a integridade do conjunto arbóreo, pois a arborização deve ser entendida como um conjunto, e não como elementos isolados. Entende-se que as qualidades artísticas da arborização urbana não estão somente nas qualidades individuais de cada exemplar, mas sim na integridade do conjunto arbóreo, o que pode ser constatado pelo levantamento fotográfico. Da mesma forma, as inserções de novos espécimes sem prévio planejamento são prejudiciais ao entendimento do conjunto. ParaBrandi (2004), é justamente essa inserção de elementos distintos dos existentes o fato mais grave, pois,ainda segundo o autor, esses elementos passam a atuar como elementos estranhos no conjunto da paisagem, não somando a ele, mas sim se contrapondo. A lacuna, neste caso, coloca-se como figura em relação ao conjunto arbóreo, que se torna o fundo para esse elemento estranho na paisagem.

Uma lacuna, naquilo que concerne à obra de arte, é uma interrupção no tecido figurativo. Mas contrariamente aquilo que se acredita, o mais grave, em relação à obra de arte, não é tanto aquilo que falta, quanto o que se insere de modo indevido. A lacuna, com efeito, terá uma forma e uma cor, não relacionadas com a figuratividade da imagem representada. Insere-se, em outras palavras, como corpo estranho. (BRANDI, 2004, p. 48-49).

A retirada das árvores dá-se pelo próprio envelhecimento do espécime, que acaba morrendo, caindo ou sendo retirado (Figura 8). Quando da inserção de um novo exemplar, não há controle sobre os espécimes plantados; a escolha fica a gosto dos próprios moradores. Em todas as unidades de paisagem pudemos observar espécimes diversos como manacá-da-serra, murta, palmeiras, aroeira-salsa, ou arbustos; no entanto, o espécime mais comum entre as inserções é o oiti (Figura9), que pode ser visto em várias vias de todas as unidades de paisagem analisadas. 
Figura 7- Simulação do projeto de arborização inicial da unidade de paisagem Zona 4

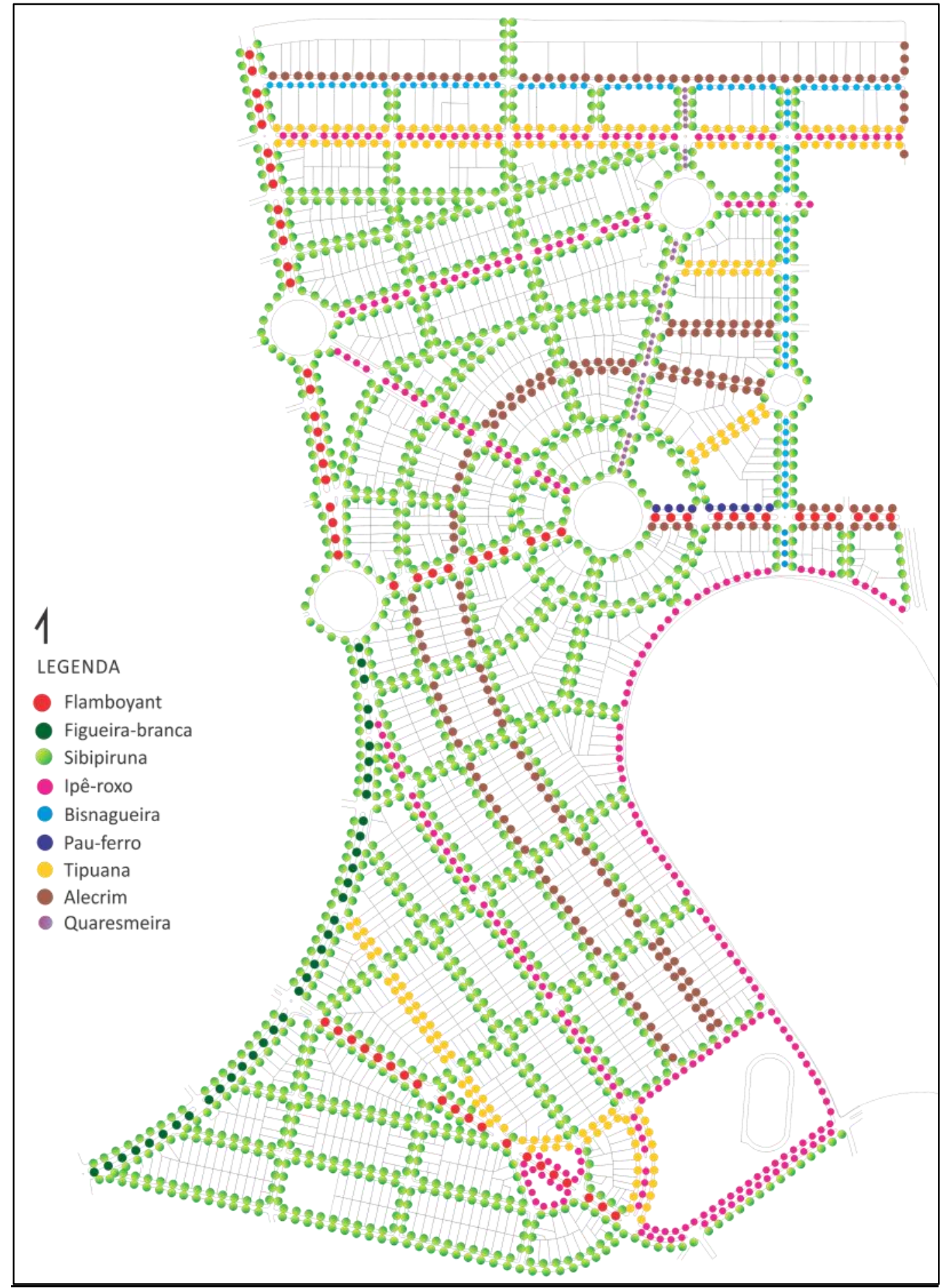

Fonte: ilustração da autora (2013).

Entre os principais conflitos identificados, um ocorre com relação ao calçamento dos passeios públicos, que acabam sendo danificados pelas raízes das árvores, e estas, por sua vez,são prejudicadas pela falta de nutrientes, proveniente da baixa quantidade de áreas permeáveis. Em vários pontos podemos observar o estrangulamento das árvores causado pela pavimentação das calçadas, que, em boa parte das situações, chega muito próximo ao tronco delas (Figura 10).Conforme argumenta Spirn (1995), pequenas mudanças no ambiente das ruas já fazem uma enorme diferença na sobrevivência da arborização. 
Figura 8 - Lacunas na Rua Agnel Canno - Zona 5

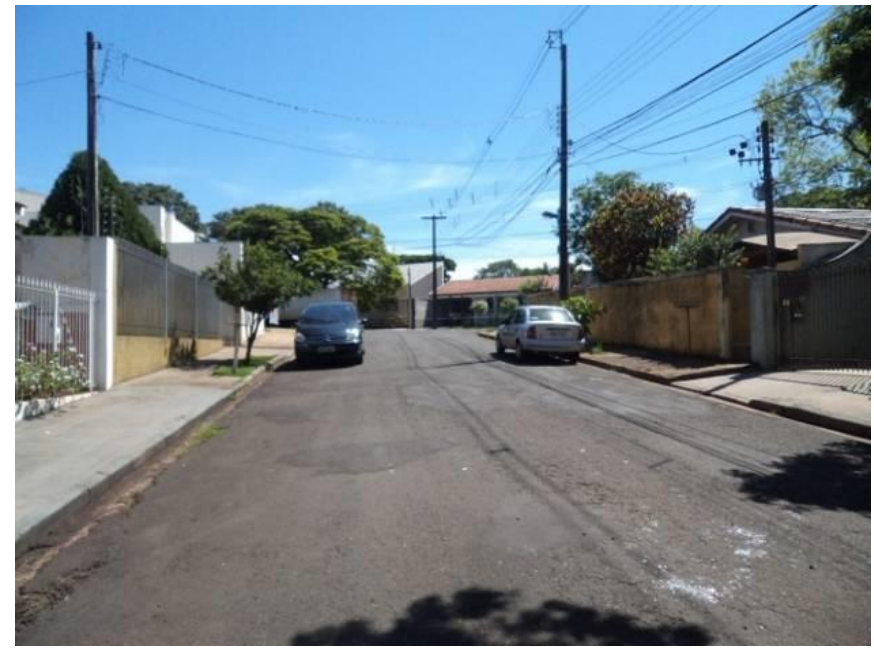

Fonte: foto da autora (2013).

Figura 9- Inserção de oitis na Rua Santa Joaquina de Vedruna - Zona 5

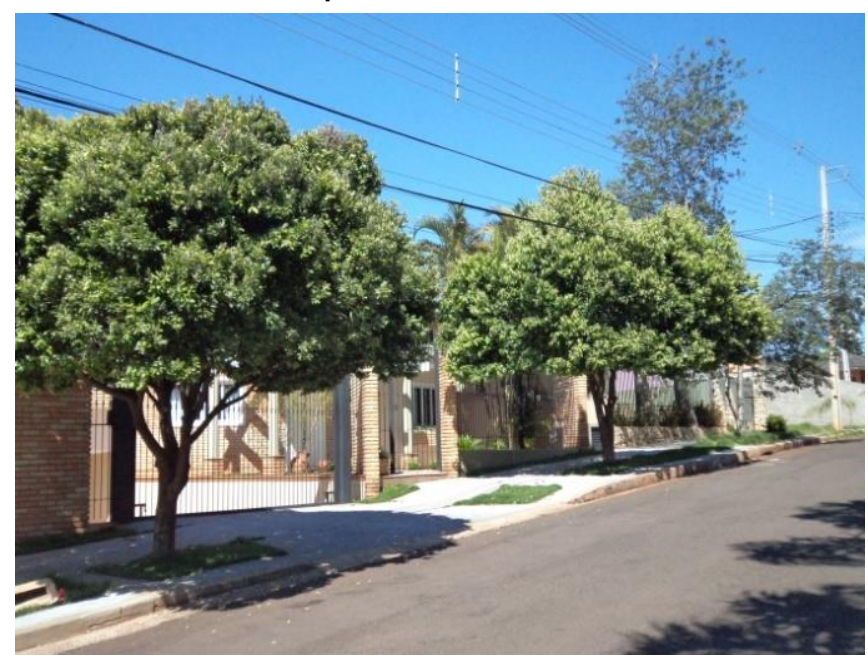

Fonte: foto da autora (2013).

Figura 10- Calçada danificada pelas raízes na Rua Benjamin Constant - Zona 7

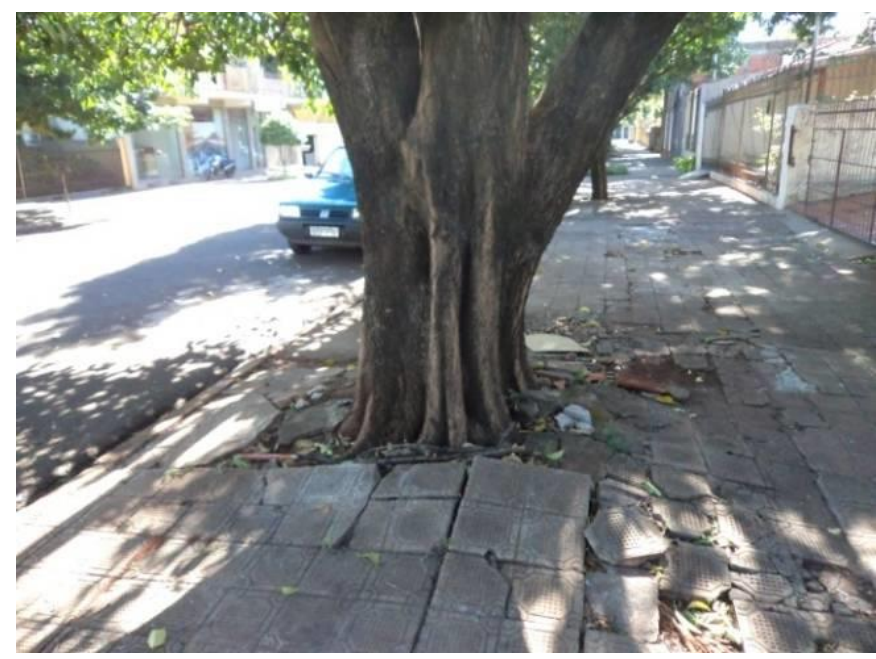

Fonte: foto da autora (2013). 
No entanto, em outros trechos, a arborização resiste à falta de áreas permeáveis e aos conflitos com as demais infraestruturas presentes no espaço das vias, e promove um grande espetáculo aos observadores.

Em algumas vias, o conjunto arbóreo preservado forma verdadeiros túneis verdes, o que proporciona uma paisagem muito bela e agradável, tanto aos olhos como ao corpo, devido ao grande sombreamento que as árvores proporcionam (Figuras 11 e 12).

Este cenário somente é possível por meio do conjunto arbóreo, ou seja, apenas uma árvore ou uma centena delas de forma isolada não são capazes de proporcionar tamanho espetáculo visual.

Os túneis verdes já são uma característica da arborização maringaense e podem ser observados em todas as unidades de paisagem; no entanto, eles foram encontrados mais comumente na unidade de paisagem Zona 7, onde as tipuanas de grande porte dão vida a uma paisagem inigualável (Figura 11). Os túneis verdes são perceptíveis na maior parte das vias do bairro.

Nas demais unidades de paisagem,o principal espécime que forma os túneis verdes é a sibipiruna, como se pode observar na Figura 12 Com copa ampla e de intenso sombreamento, as árvores proporcionam um cenário de grande beleza e melhoram as condições de conforto térmico na cidade.

As mudanças estacionais também promovem a diversidade de cores e texturas entre as árvores, seja pela coloração das florações, seja pela textura e coloração das folhas e galhos, que, ao longo do ano, com suas mudanças, vão proporcionando visuais diferentes em uma mesma paisagem. $\mathrm{Na}$ Figura 13vê-se o exemplo dos paus-ferro do canteiro central da Avenida Rio Branco, onde as folhas ganham duas tonalidades diferentes, de acordo com a estação.

Figura 11 - Túnel verde na Rua Floriano Peixoto - Zona 7

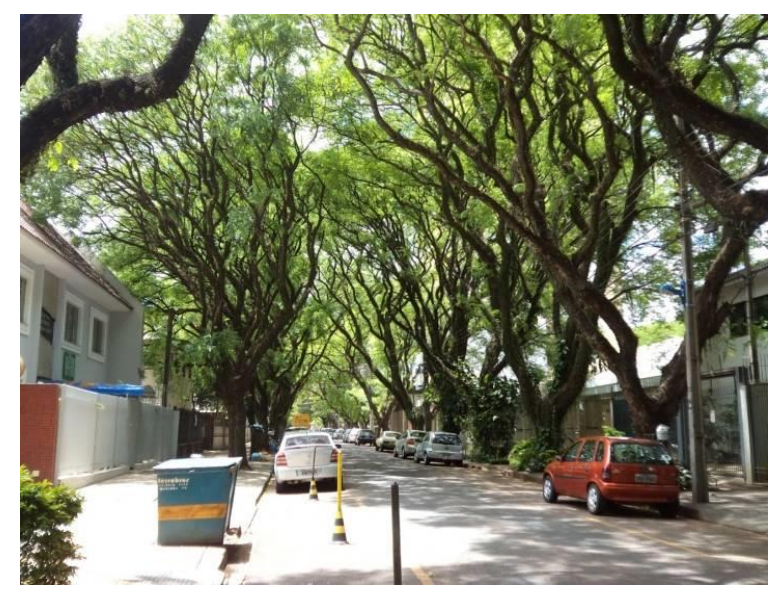

Fonte: foto da autora (2013).

Figura 12 - Sibipirunas formando túnel verde na Rua Liberdade - Zona 8

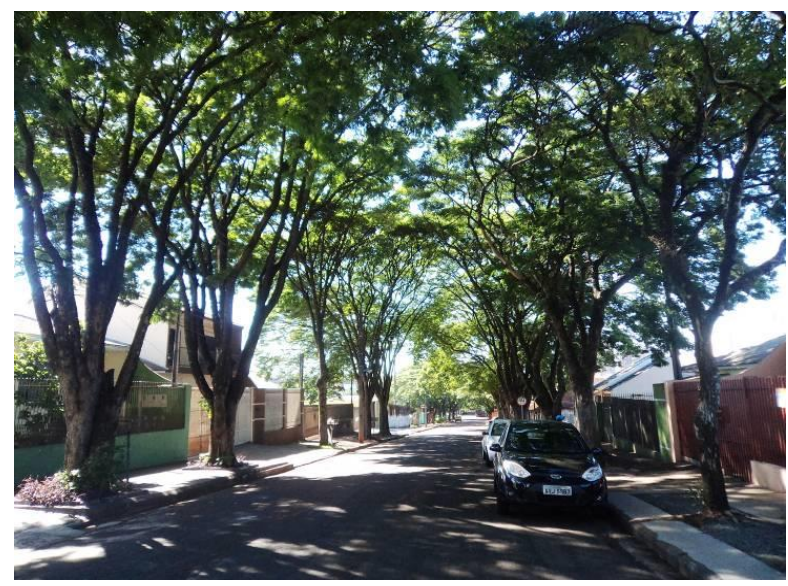

Fonte: foto da autora (2013).

110 Gonçalves, A.; Meneguetti, K. S. 
Figura 13 - Paus-ferro da Avenida Rio Branco - Zona 5

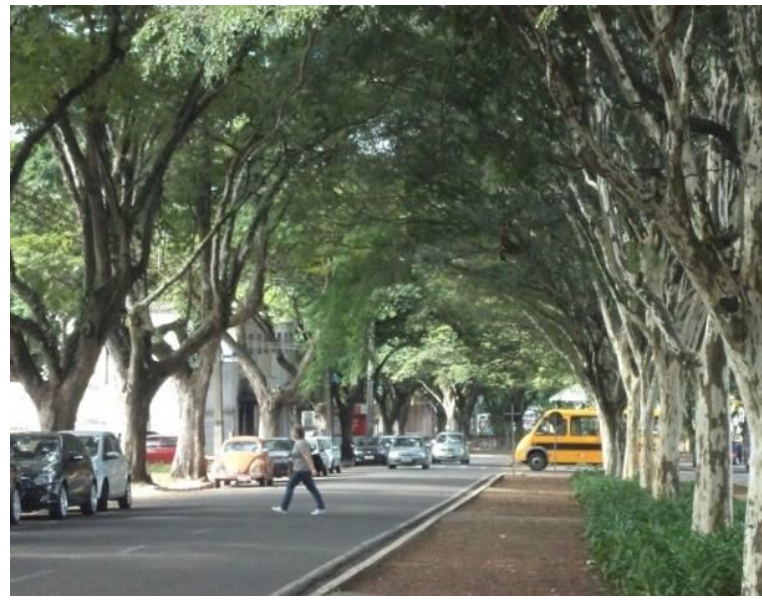

Fonte: foto da autora (2013).

Como resultado do levantamento in locoobteve-se o mapeamento das unidades de paisagem, que demonstra as áreas de predominância de lacunas existentes na arborização, os trechos com inserção de novos espécimes e os trechos onde a arborização mantém-se mais preservada em suas características.

A unidade de paisagem Zona 7 é o bairro onde o conjunto arbóreo mantém-se mais preservado. Grandes trechos ao longo das vias estão consolidados e formam verdadeiros túneis verdes. Observa-se que as tipuanas, espécime predominante no bairro, têm-se adaptado bem ao espaço disponível para seu crescimento e demais conflitos, como a falta de espaços permeáveis nos passeios. Por outro lado, a unidade de paisagem Zona 6 é a área onde o conjunto arbóreo encontrase mais deteriorado. Nesta unidade de paisagem, a unidade do conjunto encontra-se prejudicada, são muito comuns as lacunas, grandes trechos sem arborização e outros trechos onde novos espécimes têm sido implantados. O mesmo ocorre em um trecho grande da unidade de paisagem Zona 8, onde a arborização também se encontra prejudicada, assim como na unidade de paisagem Zona 4, em sua porção mais próxima à área central da cidade, onde predominam os usos comercial e de serviços.

No entanto, as lacunas são comuns em todas as unidades de paisagem analisadas, ora em maior, ora em menor quantidade. Na unidade de paisagem Zona 5, por exemplo, percebe-se grande número de inserções de novos espécimes, fato comum também nas demais unidades de paisagem. Entre os espécimes inseridos, os principais são o oiti (Licania tomentosa), a aroeira-salsa (Schinus molle) e a murta (Murraya paniculata), além de arbustos diversos.

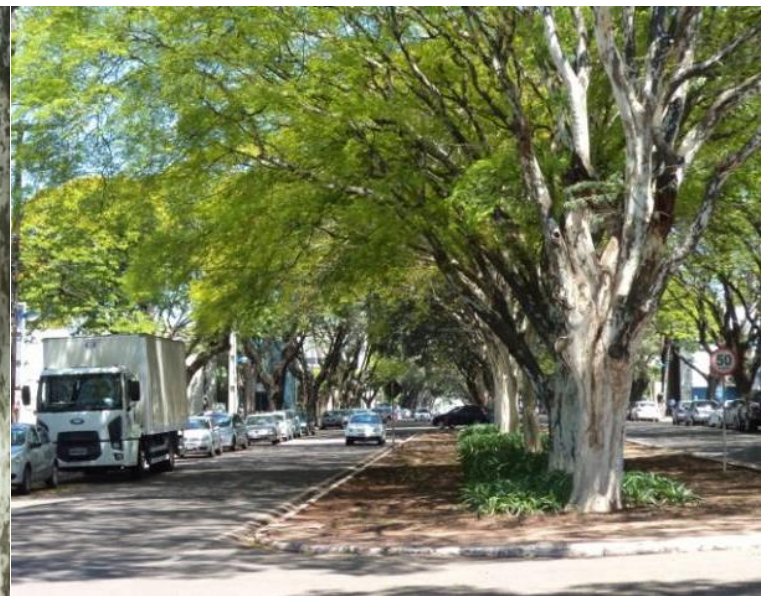

\section{Plano de recomposição da arborização}

A quarta etapa da pesquisa foi a proposta de intervenção no projeto de arborização de Maringá, que tem por objetivo manter a qualidade estética da paisagem existente, suas características e sua forte identidade com a população. Visa unir as qualidades estéticas oriundas da arborização de vias às soluções para a incompatibilidade de parte dessa arborização com as demais formas de infraestrutura urbana e edificações.

Esta pesquisa propõe um projeto de rearborização que resgata e fortalece a paisagem criada pelo projeto de arborização inicial de Luiz Teixeira Mendes, de forma a preservar parte do patrimônio paisagístico de Maringá.

Segundo Spirn (1998), o projeto é um meio de imaginar e contar novas histórias e de reviver antigas, um processo de expressar visões da paisagem, descrevendo a forma de um futuro possível.

O projeto de rearborização proposto conta com a especificação de novos espécimes que possam ser plantados em substituição aos exemplares originais que necessitem ser retirados, por motivos de doença ou envelhecimento natural. Os espécimes escolhidos visam manter as características de sombreamento, qualidade estética, porte adequado ao espaço destinado a seu plantio e adequação às demais formas de infraestrutura urbana, como fiação elétrica, redes de saneamento básico, pavimentação dos passeios e edificações.

Importante também é que esses espécimes sejam, em sua maioria, nativos, para valorizar a flora da região e minimizar a inserção de espécimes exóticos, muito comum na atividade de arborização urbana. 
Em Maringá, a grande quantidade de exemplares do espécime sibipiruna (Caesalpinia peltophoroides) implantados ao longo do plano inicial e em outros pontos da cidadepode, como citado por Milano (1988) e Sampaio (2006), facilitar a disseminação de doenças e pragas, e levar à deterioração da arborização. Dessa forma, o projeto de rearborização tem por objetivo dar maior variedade aos espécimes implantados na arborização de vias, como defendem Grey e Deneke (1978), estabelecendo que a existência de um mesmo espécime não deve ultrapassar $15 \%$ do total.No projeto de recomposição da arborização proposto nesta pesquisa, as unidades de paisagem foram pensadas individualmente, portanto a percentagem de variedade de espécimes de $15 \%$ foi considerada para cada unidade de paisagem.

A preferência deu-se por espécimes de floração exuberante, de coloração variada, que possuam troncos e galhos resistentes e não tortuosos, o que evita a obstrução dos passeios e conflitos diretos com as edificações. Vale lembrar que a escolha dos espécimes especificados no projeto de rearborização foi uma atitude projetual, que considerou, além das questões técnicas, as características que visam valorizar e preservar o projeto inicial de Luiz Teixeira Mendes. A questão estética é de forte apelo na área urbana, como demonstrado por Johnson $\left(1997^{2}\right.$ apud THOMPSON; STEINER, 1997) e por Hough (1995).

O principal objetivo desta proposta é manter a unidade do conjunto arbóreo, no entanto a unidade não significa que todos os espécimes devam ser iguais, ou de mesmo porte. A proposta deste projeto de rearborização é que a unidade dê-se por vias, ou seja, cada via conterá um único espécime em toda a sua extensão, o que formará o conjunto arbóreo do bairro e, consequentemente, o conjunto arbóreo do plano inicial da cidade.Assim, a unidade da via é mantida, porém a maior variedade dos espécimes é alcançada; além disso, a diferenciação e a identidade das vias são reforçadas pelo espécime arbóreo nela implantado, seguindo a ideia do plano inicial.
Portanto, o espécime escolhido deve ser implantado em ambos os lados da via, pois se concluiu que a presença da fiação elétrica e a poda da copa da árvore não têm ligação direta com a existência de lacunas na arborização, e que as árvores, de maneira geral, têm-se adaptado bem às podas necessárias à passagem da fiação adotada em Maringá, do tipo compacta. O formato das árvores e copas permite a passagem da fiação elétrica sem que sejam necessárias podas drásticas. Isso leva a crer que utilizar apenas árvores de pequeno porte nos passeios onde haja fiação não é a única alternativa; ao contrário, é possível compatibilizar árvores de médio porte com a rede elétrica.

A Figura 14ilustra a composição do projeto de rearborização da unidade de paisagem Zona 4.

Como a área pertencente ao plano inicial de Maringá conta com vias largas e passeios com uma média de $4 \mathrm{~m}$ de largura, o cenário é propício à implantação de arborização. No caso das vias residenciais, o objetivo é proporcionar, além de qualidade estética, sombreamento nos passeios e edificações. Assim, a opção é por espécimes de médio e grande porte que possam atender aos requisitos estéticos e aos de conforto bioclimático. Como na maior parte dos bairros os passeios são largos e o recuo obrigatório é de no mínimo $3 \mathrm{~m}$, tem-se a possibilidade de acomodar tais espécimes sem que haja conflito com as edificações.As vias residenciais de todas as unidades de paisagem devem seguir o modelo exposto nas Figuras 15 e 16.

\footnotetext{
2 JOHNSON, M. Ecology and Urban Aesthetic. In: THOMPSON, G.; STEINER, F. R. Ecological Design andPlanning. New York> John Wiley\&Sons, 1997.
} 
Figura 14 - Projeto de rearborização da unidade de paisagem Zona 4

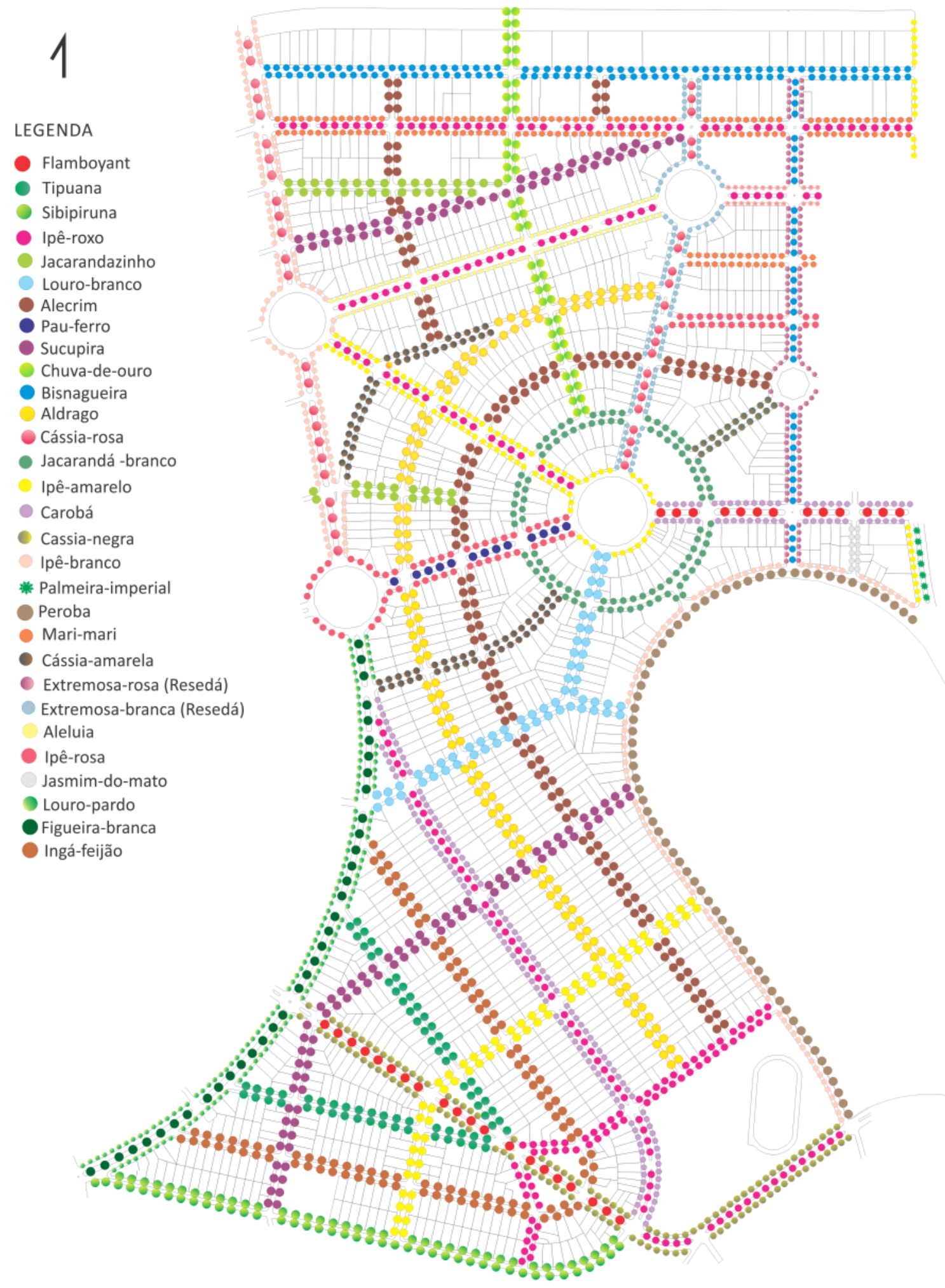

Fonte: ilustração da autora (2014). 
Figura 15- Proposta para ruas residenciais - Planta

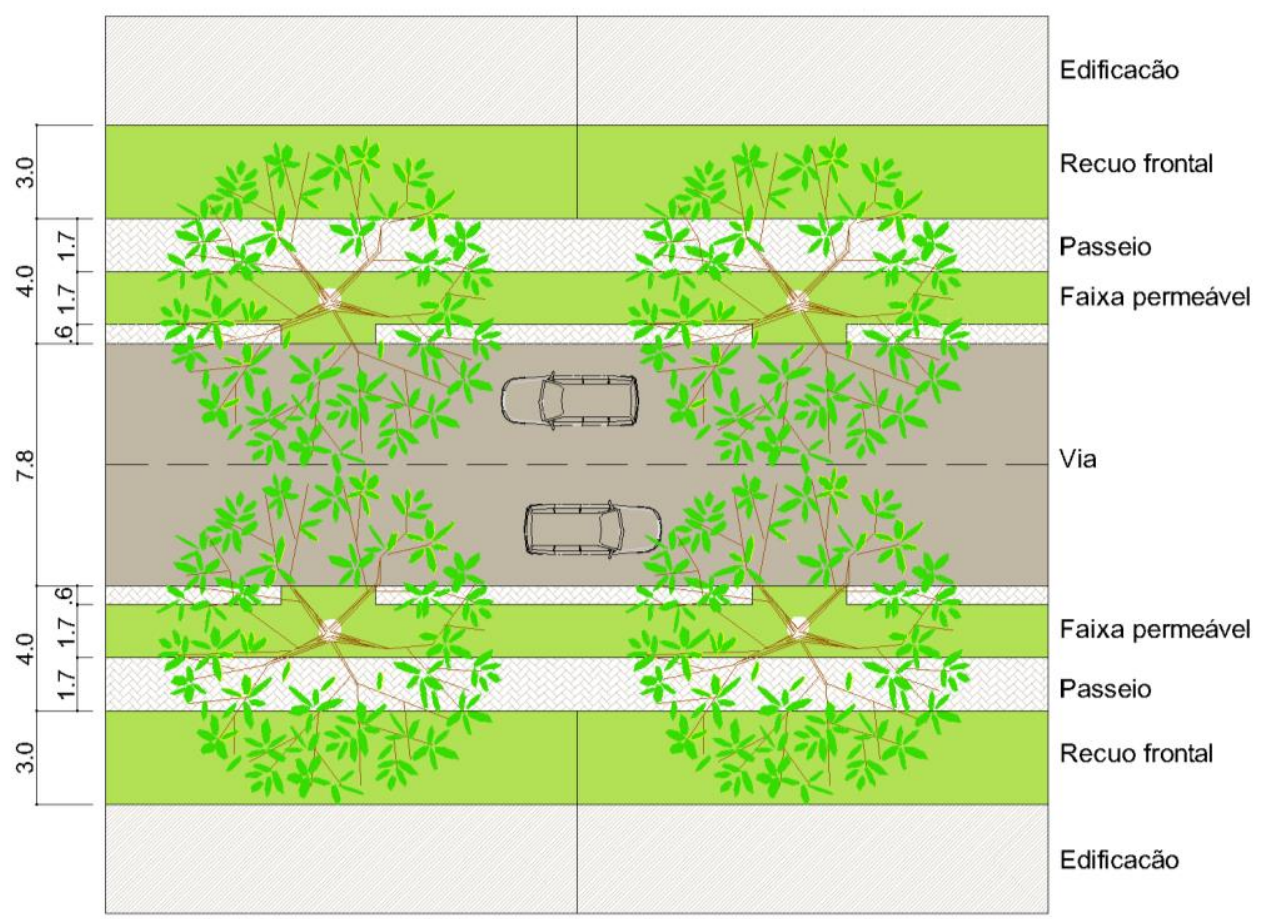

Fonte: ilustração da autora (2013).

Figura 16- Proposta para ruas residenciais - Corte

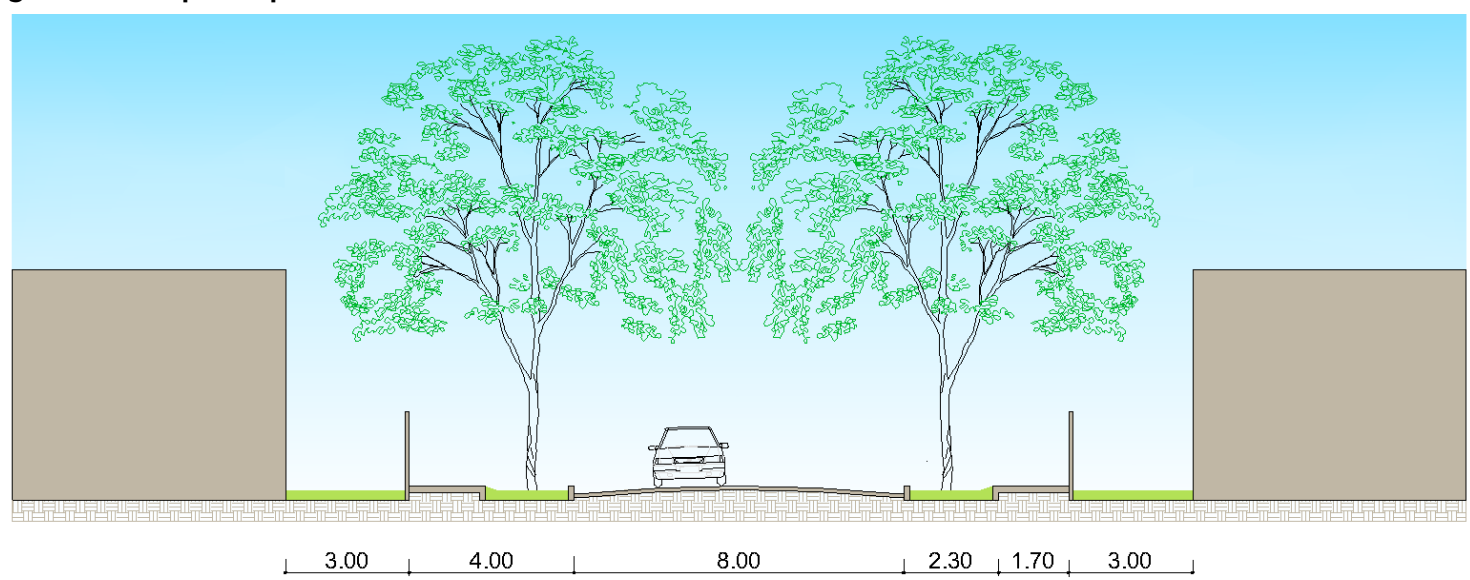

Fonte: ilustração da autora (2013).

Nos casos em que haja alguma particularidade, como vias onde os passeios são mais estreitos, inferiores a $3 \mathrm{~m}$, as árvores implantadas devem considerar o espaço disponível, sendo implantado preferencialmente um espécime de pequeno porte. A opção será por espécimes de floração exuberante, que possam promover sombreamento, e com troncos e galhos que não obstruam a circulação de pedestres nos passeios (Figura 17).

Com respeito ao projeto de rearborização, nas vias comerciais, onde as edificações, em sua maioria, ficam no alinhamento predial e é comum haver marquises e letreiros que avançam sobre os passeios, a escolha deu-se por espécimes de pequeno e médio porte, com os quais sejam garantidas as qualidades estéticas, proporcionadas principalmente pelas florações, e a visibilidade das fachadas e adaptação ao espaço dos passeios, que, apesar de terem em média $5 \mathrm{~m}$ de largura, devido ao grande fluxo de pedestres, devem reservar maior espaço livre de obstáculos para livre circulação dos transeuntes. 


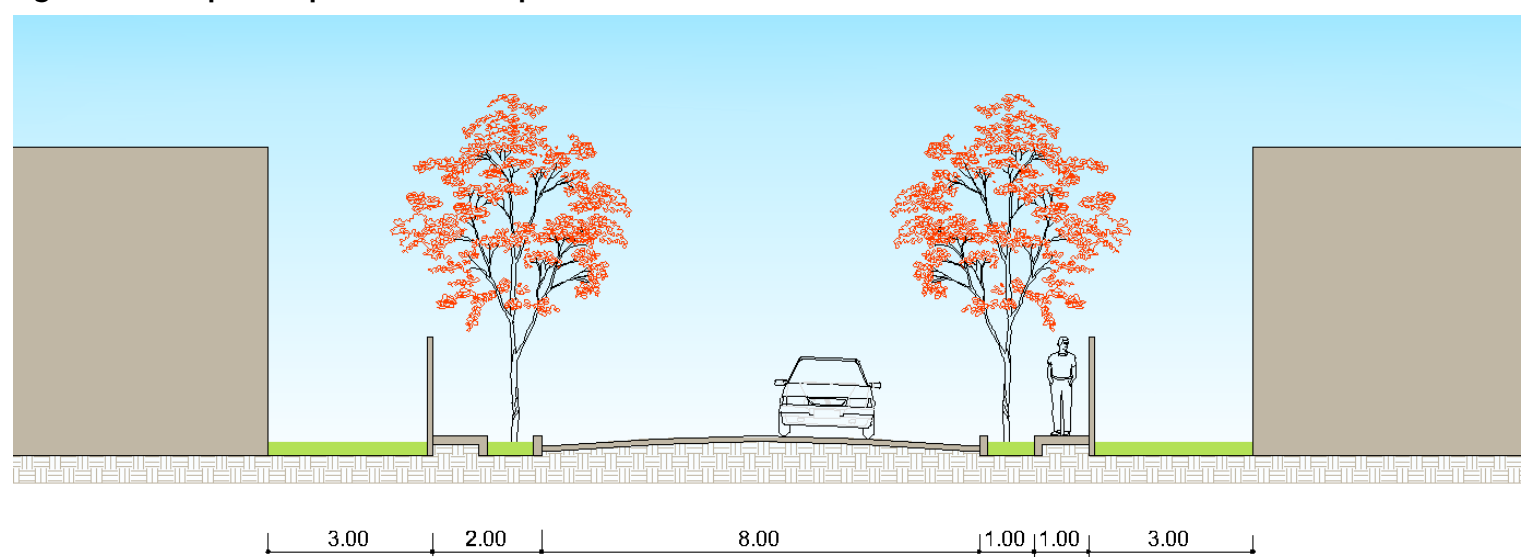

Fonte: ilustração da autora (2013).

No canteiro central, tem-se a possibilidade de implantação de espécimes de médio e grande porte, de acordo com o espaço disponível. $\mathrm{Na}$ maior parte dos casos, serão mantidos os espécimes já implantados no plano de arborização inicial, como o flamboyant, um dos símbolos da arborização de Maringá, presente no canteiro de algumas das principais vias da cidade. Sua floração de um vermelho intenso encanta os moradores e visitantes, e atribui valor estético à paisagem da cidade.

A manutenção dos espécimes dos canteiros centrais visa à preservação do plano de arborização inicial. Lembra-se que, para cada via, Teixeira Mendes buscou utilizar um espécime que a identificasse, dando identidade a cada uma das vias. O modelo para avenidas comerciais segue o ilustrado nas Figuras 18 e 19.

Entende-se que a paisagem formada pela arborização, dada principalmente por seu porte e formato das copas, faz parte da imagem dos bairros e da cidade. Dessa forma, esta é uma característica importante a ser respeitada quando da proposta de substituição de espécimes. Tem-se, então, o desafio de encontrar espécimes que garantam um porte compatível ao da paisagem atual e que garantam a formação dos admirados túneis verdes sobre as vias, compatibilizando-se com os passeios, fachadas e demais infraestruturas urbanas, sejam elas subterrâneas ou aéreas.

\section{Conclusões}

Considerando-se o conjunto arbóreo implantado como parte integrante do patrimônio e identidade da cidade, as medidas para salvaguardar esse bem tornam-se imprescindíveis. A preservação da arborização, por sua vez, depende do conhecimento e do entendimento dela por parte da população como patrimônio da cidade.

A principal contribuição que esta pesquisa pode prestar à preservação e à manutenção do conjunto arbóreo é a identificação da arborização por meio de seu processo histórico, investigando a forma de espacialização do projeto original e os resultados das transformações ocorridas desde sua implantação; em um segundo momento, propor aformatação de um projeto de rearborização para a porção mais antiga da cidade, onde a arborização implantada pelo projeto de arborização inicial envelhece e, em algumas áreas, pede por socorro.

O processo de envelhecimento da vegetação é natural, afinal se trata de um elemento vivo, que cresceu e desenvolveu-se juntamente com a cidade e seus elementos construídos, testemunhou a modificação da paisagem urbana de uma cidade de pujante crescimento. Justamente por isso essa vegetação faz parte do cotidiano e da história do cidadão maringaense, acostumado a presenciar todos os anos um verdadeiro show da natureza, promovido pelas florações, pelas mudanças estacionais e pelo produto final construído por essa arborização, a paisagem urbana, difícil de ser encontrada em outras cidades da região e do país. 
Figura 18- Proposta para avenidas - Corte

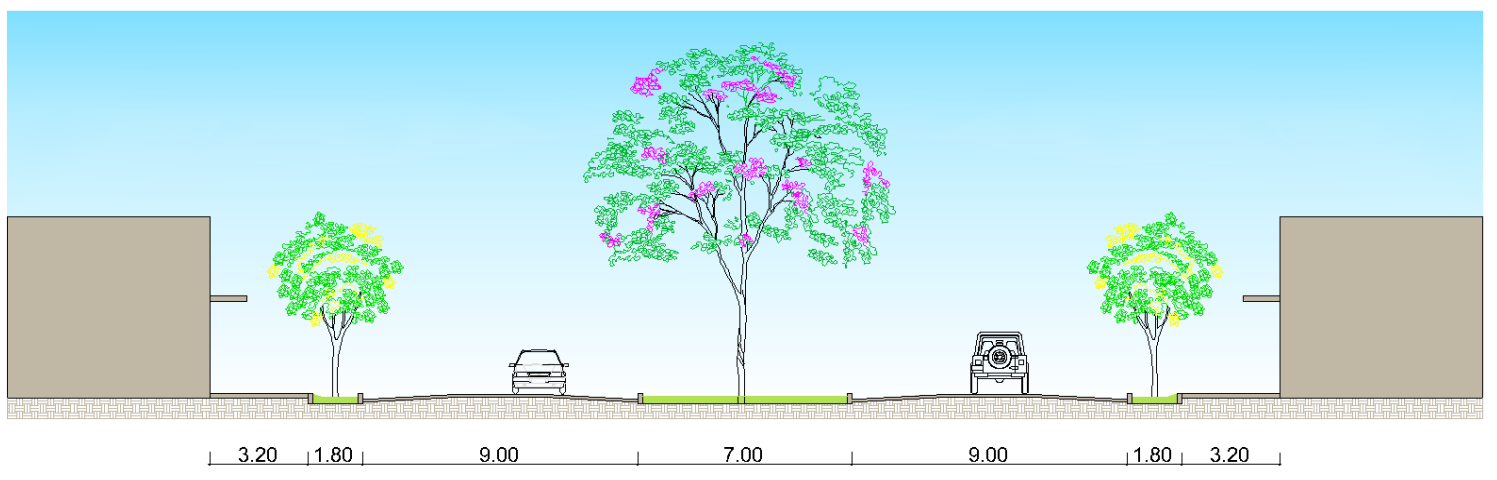

Fonte: ilustração da autora (2013).

Figura 19- Proposta para avenidas - Planta

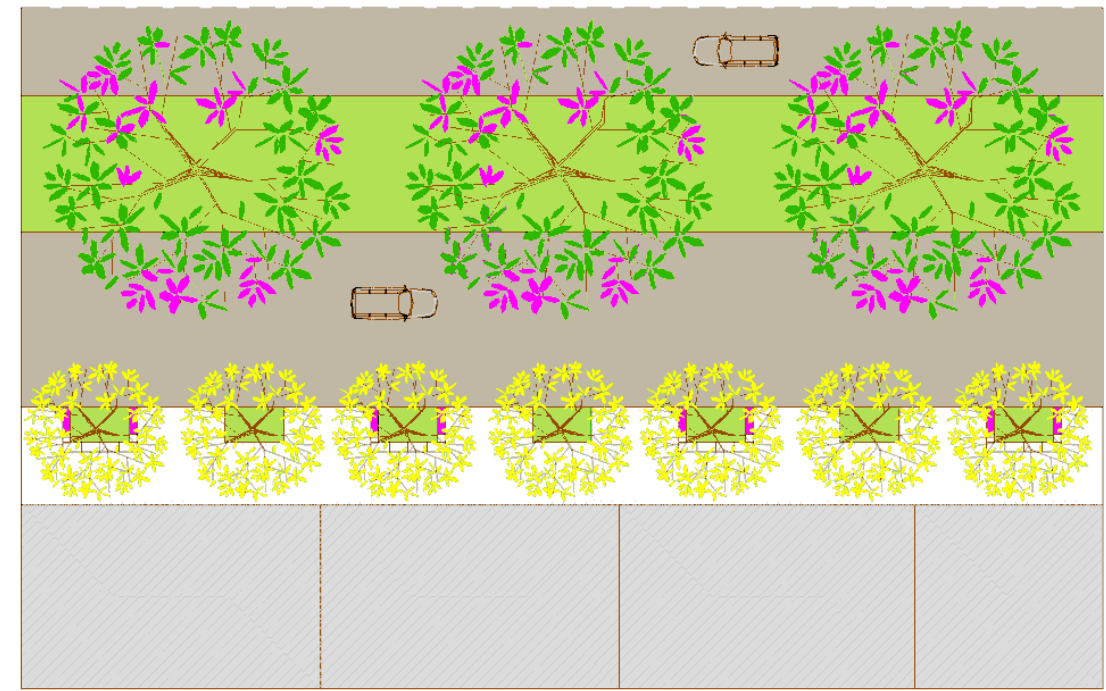

Fonte: ilustração da autora (2013).

Dessa forma, o projeto de rearborização proposto por esta pesquisa busca resgatar a figuratividade proposta pelo projeto inicial, assim como a paisagem construída por ele. $\mathrm{O}$ projeto propõe a preservação, a substituição e a ampliação dos espécimes arbóreos implantados no plano inicial da cidade. $O$ projeto ressalta a preservação e a manutenção dos espécimes existentes nesse recorte urbano, principalmente os implantados nos canteiros centrais, visando à preservação do projeto paisagístico inicial, entendido como patrimônio da cidade e tendo em vista o levantamento in loco realizado nesta pesquisa, que detectou que, nos canteiros centrais, onde a vegetação encontra condições de espaço suficientes para desenvolver-se, os espécimes encontram-se bem consolidados.

Cada espécime foi escolhido e espacializado por meio de critérios específicos de porte, características arbóreas e estéticas, visando preservar e resgatar a esteticidade do projeto inicial de arborização elaborado e implantado por Luiz Teixeira Mendes e Aníbal Bianchini da Rocha.

Uma vez que a arborização urbana seja entendida como patrimônio da cidade, o conjunto arbóreo terá maior possibilidade de que suas qualidades históricas e estéticas sejam preservadas. A partir desse momento, a arborização deixa de ser apenas um elemento da infraestrutura urbana e adquire realmente o patamar de patrimônio da cidade, podendo tornar-se um elemento fundamental para a qualidade urbana.

Esta pesquisa torna-se importante por tratar da temática arborização viária de um ponto de vista original, ou seja, entendendo o projeto de arborização como patrimônio histórico da cidade de Maringá. Por esse motivo, a pesquisa requereu a construção de uma metodologia específica capaz de apreender o patrimônio arbóreo da cidade. A 
metodologia de pesquisa parte da simulação da distribuição espacial da arborização de acordo com o projeto original, iniciado na década de 1950, e é finalizada com a proposição de um projeto de rearborização para o plano inicial da cidade.

Com relação à aplicação deste projeto, conclui-se que as unidades de paisagem Zona 6 , Zona 8 e Zona 4 são as áreas prioritárias para a implantação do plano de rearborização, porque nessas áreas o conjunto arbóreo encontra-se mais prejudicado, com diversas lacunas e inserções de novos espécimes arbóreos, diferentes dos implantados no plano inicial. Assim, essas áreas requerem maior atenção voltada a sua arborização viária, o patrimônio verde da cidade.

\section{Referências}

ANDRADE, C. R. M.; CORDOVIL, F. C. S. A cidade de Maringá, PR: o plano inicial e as "requalificações urbanas". In:COLÓQUIO INTERNACIONAL DE GEOCRÍTICA, 10., Barcelona, 2008. Proceedings... Barcelona, 2008.

BENEVOLO, L. A cidade e o Arquiteto: método e história na arquitetura. São Paulo: Perspectiva, 2004.

BRANDI, C. Teoria da Restauração. Cotia: Ateliê, 2004.

CHOAY, F. A Alegoria do Patrimônio. 4. ed. São Paulo: Estação Liberdade, 2006.

GREY, G. W.; DENEKE, F. J. Urban Forestry. New York: John Wiley, 1978.

GUIA GEOGRÁFICO. Mapa Turístico do

Paraná. Disponível em: <http://www.paranaturismo.com/mapa-parana.htm $>$. Acesso em: 09 mar. 2015.

INSTITUTO DO PATRIMÔNIO HISTÓRICO E ARTÍSTICO NACIONAL. 2013. Disponível em: <http://portal.iphan.gov.br>. Acesso em: 12 jan. 2015.

HOUGH, M. Cities and Natural Process. Nova York: Routledge, 1995.

LYNCH, K. A Imagem da Cidade. São Paulo: Martins Fontes, 1999.

MACEDO, J. Maringá: a British Garden City in the tropics. Cities, v. 28, n. 4, p. 347-359, 2011.

MENEGUETTI, K. S. Desenho Urbano e Qualidade de Vida: o caso de Maringá - PR. Maringá, 2001. Dissertação (Mestrado em Geografia) - Faculdade de Geografia, Universidade Estadual de Maringá, Maringá, 2001.
MENEGUETTI, K. S. Maringá: o desenho urbano, a imagem da cidade e a qualidade de vida. In: MORO, D. Á. Maringá Espaço e Tempo. Ensaio de Geografia Urbana. Maringá: Programa de PósGraduação em Geografia, UEM, 2003.

MENEGUETTI, K. S. Cidade-Jardim, Cidade Sustentável: a estrutura ecológica urbana e a cidade de Maringá. Maringá: Eduem, 2009.

MENEGUETTI, K. S.; REGO, R. L.;

PELLEGRINO, P. R. M. A Natureza no Cotidiano Urbano: o projeto da paisagem na cidade de Maringá. Acta Scientiarum. Technolody, Maringá, v. 27, n. 2, p. 167-173, jul./dec. 2005.

MENEGUETTI, K. S.; REGO, R. L.; BELOTO, G. E. Maringá: a paisagem urbana e o sistema de espaços livres. Paisagem Ambiente: Ensaios, São Paulo, v. 26, p. 29-50, 2009.

MENEGUETTI, K. S. et al. A Cidade, as Árvores e a Paisagem Cultural. In: COLÓQUIO IBEROAMERICANO PAISAGEM CULTURAL, PATRIMÔNIO E PROJETO: DESAFIOS E PERSPECTIVAS, Belo Horizonte, 2010. Anais... Belo Horizonte, 2010.

MILANO, M. S. Avaliação Quali-Quantitativa e Manejo da Arborização Urbana: exemplo de Maringá. Curitiba, 1988. Tese (Doutorado em Geografia) - Faculdade de Geografia, Universidade Federal do Paraná, Curitiba, 1988.

PREFEITUERA MUNICIPAL DE MARINGá. Portal Cidadão. Disponível em: <http://geoproc.maringa.pr.gov.br:8090/PORTAL CIDADAO/>. Acesso em: 09 mar. 2015.

RECCO, R. À Sombra dos Ipês da Minha Terra. Londrina: Midiograf, 2005.

REGO, R. L. O Desenho Urbano de Maringá e a Idéia de Cidade-Jardim. Acta Scientiarum.

Technology, Maringá, v. 23, n. 6, p. 1569-1577, 2001.

SAMPAIO, A. C. F. Análise da Arborização de Vias Públicas das Principais Zonas do Plano Piloto de Maringá-PR. Maringá, 2006.

Dissertação (Mestrado em Geografia) - Faculdade de Geografia, Universidade Estadual de Maringá, Maringá, 2006.

SPIRN, A. W. O Jardim de Granito: a natureza no desenho da cidade. São Paulo: Edusp, 1995.

SPIRN, A. W. The Language of Landscape. New Haven; London: Yale University Press, 1998.

THOMPSON, G. F.; STEINER, F. R.

(Eds.).Ecological Design and Planning. Nova York: John Wiley, 1997. 
SILVEIRA, A. M. da et al. Unidade e Unicidade: o papel da arborização urbana em Maringá. In:CONGRESSO BRASILEIRO DE ARBORIZAÇÃO URBANA,10., Maringá, 2006.Anais... Maringá, 2006.
UNWIN, R. La Practica del Urbanismo: una introducción al arte de proyectar ciudades y barrios. Barcelona: GG, 1984.

\section{Revista Ambiente Construído}

Associação Nacional de Tecnologia do Ambiente Construído

Av. Osvaldo Aranha, $99-3^{\circ}$ andar, Centro

Porto Alegre - RS - Brasil

CEP 90035-190

Telefone: +55 (51) 3308-4084

Fax: +55 (51) 3308-4054

www.seer.ufrgs.br/ambienteconstruido

E-mail: ambienteconstruido@ufrgs.br 